\title{
ФЛОТАЦИЯ МОЛИБДЕНА(VI) И ВОЛЬФРАМА(VI) ИЗ КИСЛЫХ ТЕХНОЛОГИЧЕСКИХ РАСТВОРОВ
}

\author{
(Представил О. Эйзен)
}

Процессы ионной флотации молибдена и вольфрама хорошо изучены $\left[{ }^{1-3}\right]$ и уже нашли промышленное применение $\left[{ }^{4,5}\right.$. По известным способам флотация этих элементов осуществляется в присутствии катионных собирателей из слабокислых растворов - $\mathrm{pH} \sim 3$ для молибдена и $\mathrm{pH} \sim 0,5$ и выше для вольфрама. Наивысшая, по данным [6], концентрация молибдена во флотируемом растворе составляет 2,24 г/дм ${ }^{3}$.

B рамках настоящей работы исследована флотируемость молибдена (VI) и вольфрама(VI) из двух технологических растворов, в которых концентрации как кислоты, так и извлекаемых элементов значительно превышают ранее изученные пределы.

\section{Әкспериментальная часть}

Флотация молибдена. Первый технологический раствор представлял собой темно-зеленую с резким запахом жидкость удельного веса $1,139 \mathrm{\kappa г} /$ дм $^{3}$. Его состав: свободная азотная кислота - 3,05 мол/дм ${ }^{3}$,

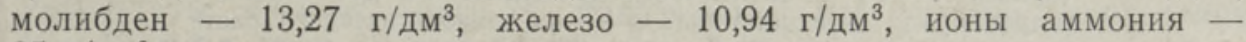
$25 \mathrm{\Gamma} /$ дм $^{3}$.

Десятикратным разбавлением раствора водой доводили конъюнктурную концентрацию молибдена до его ионной флотации. Величина pH получаемого раствора составляла 0,9. Далее исследовали эффективность извлечения молибдена и железа в пену в зависимости от количества прибавляемого в качестве собирателя гидрохлорида додециламина при $\mathrm{pH}$ раствора $0,9-2,2$. В процессе регулирования кислотности, в растворах с рH 1,4 и выше, образовывалась буроватого цвета муть, софлотировавшаяся с.ионами молибдена. Более кислые растворы были прозрачны.

Анализ данных (рис. $1, a)$ показывает, что начиная с определенного соотношения амина и молибдена степень извлечения молибдена в пену превышает 90\% при всех изученных значениях рН. Следовательно, молибден проявляет способность к флотации в более кислых растворах, чем известно по предыдущим работам. При повышении величины pH степень полимеризации молибдена повышается, отчего расход амина снижается, а степень софлотации железа повышается. При рН 1,3 и ниже извлечение железа в пену не превышает $7 \%$.

Представляло интерес выяснить, флотируется ли молибден из еще более кислых и более концентрированных в отношении его растворов. С этой целью была проведена серия опытов по извлечению молибдена и железа в пену прямо из первого технологического раствора и из растворов, полученных после его 2-, 5- и 10-кратного разбавлений. 


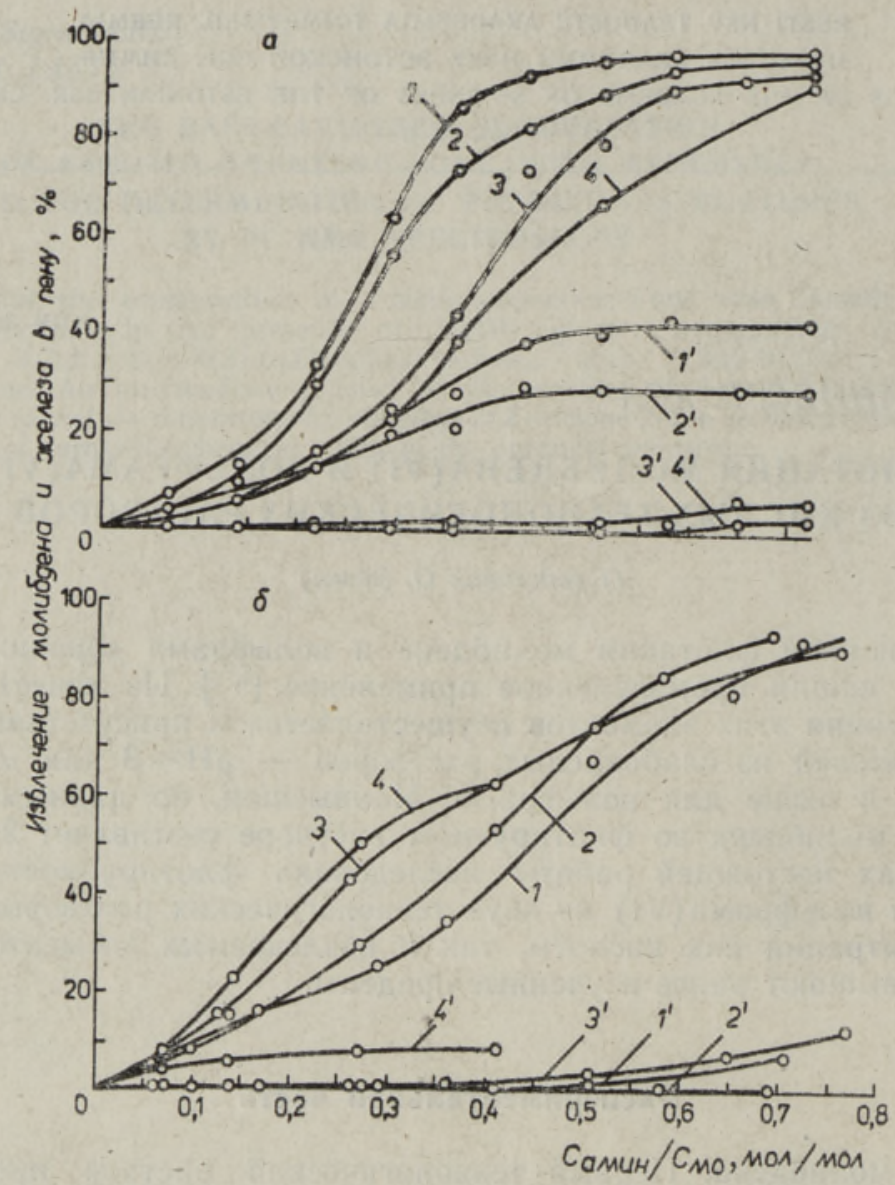

Рис. 1. Флотируемость молибдена (кривые $1-4$ ) и железа (кривые $\Gamma^{\prime}-4^{\prime}$ ) в зависимости от количества добавляемого гидрохлорида додециламина: $a-$ из технологического раствора, разбавленного $1: 9$, при $\mathrm{pH} 2,2$ (кривые $1, l^{\prime}$ ), 1,7 $\left(2,2^{\prime}\right), 1,3\left(3,3^{\prime}\right)$ и $0,9^{\prime}\left(4,4^{\prime}\right) ; 6-$ из технологических растворов, разбавленных 1:9 (кривые $\left.1, I^{\prime}\right), 1: 4$ (2 2'), $1: 1\left(3,3^{\prime}\right)$, и из неразбавленного раствора $\left(4,4^{\prime}\right)$ без регулирования $\mathrm{pH}$.

Содержание молибдена во флотируемых растворах составляло 13,27 ; 6,$64 ; 2,65$ и 1,33 г/дм ${ }^{3}$, железа - 10,$94 ; 5,47 ; 2,19$ и 1,09 г/дм² ${ }^{3}$, а концентрация свободной азотной кислоты $-3,05 ; 1,52 ; 0,61$ и 0,30 мол/дм ${ }^{3}$. Собиратель гидрохлорид додециламина в виде его 0,1 молярного спиртового раствора постепенно прибавляли в раствор до образования обильной пены или нефлотируемой мути - признаков, указывающих на избыток собирателя.

Результаты опытов (рис. 1, б) свидетельствуют о том, что извлечение молибдена в пену из всех разбавленных растворов протекает успешно. В неразбавленном растворе при постепенном прибавлении гидрохлорида додециламина, начнная с соотношения $\mathrm{C}_{\text {амин }} / \mathrm{C}_{\mathrm{Mo}_{0}}=$ $=0,27$ мол/мол, образуется белого цвета нефлотируемая суспензия В опытах с 2-кратным или большим разбавлением исходного раствора, т. е. начиная уже с концентрацни азотной кислоты 1,52 мол/дм ${ }^{3}$, степень извлечения молибдена в пену достигает $90 \%$. Расход амина составляет $0,6-0,8$ мол/Г-атом Мо и растет с повышением ионной силы, т. е. с понижением степени разбавления раствора. Степень соизвлечения железа остается во всех проведенных опытах ниже $10 \%$. 
Рнс. 2. Флотнруемость вольфрама в зависимости от количества прибавляемого гидрохлорида додециламина из технологических растворов, разбавленных $1: 9$ (крнвая $I), 1: 4(2), 1: 1 \cdot(3)$, и из неразбавленного раствора (4).

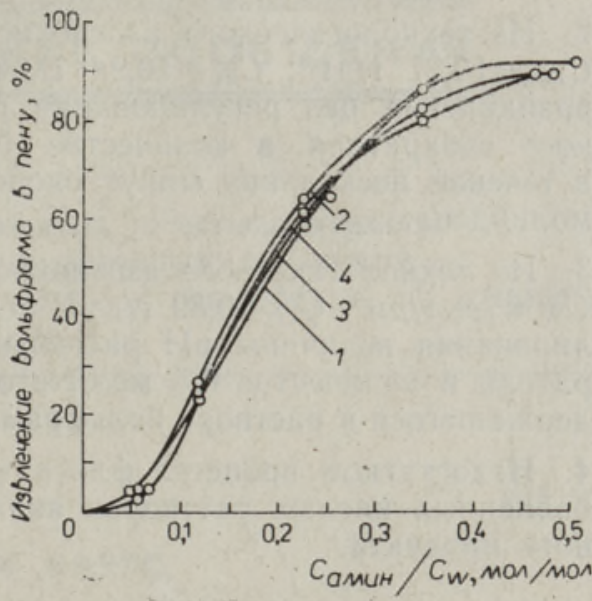

В сухом концентрате, полученном при флотации молибдена из разбавленного 1:1 технологического раствора, содержание молибдена составляло $27 \%$, додециламина $41 \%$ и железа $0,12 \%$. Остальные металлы, по данным спектрального анализа,' присутствовали только в следовых количествах.

Флотация вольфрама. Второй раствор представлял собой темно-желтую с резким запахом жидқость удельного веса $1,305 \mathrm{kr} /$ дм $^{3}$. Его состав: свободная азотная кислота $-6,48$ мол/дм ${ }^{3}$, вольфрам $-7,9 \mathrm{r}^{2}$ дм $^{3}$, железо - 0,89 г/дм ${ }^{3}$, кальций -55 г/дм³

Так как молибден успешно флотировался из раствора, содержащего даже 1,52 мол/дм ${ }^{3}$ свободной азотной кислоты (рис. 1,б), аналогичные опыты по расходу амина при различных разбавлениях были проведены и в случае вольфрамового раствора. Концентрация вольфрама во флотируемых растворах была 7,$9 ; 3,95 ; 1,58$ и 0,79 г/дм ${ }^{3}$, а концентрация азотной кислоты - 6,$48 ; 3,24 ; 1,30$ и 0,65 мол/дм ${ }^{3}$. Результаты опытов (рис. 2) показывают, что степень извлечения вольфрама в пену из всех изученных растворов, включая и неразбавленный, очень высока - достигает приблизительно $90 \%$. Расход амина составляет $0,4-0,5$ мол/г-атом W. Ионы кальция, количество которых в растворе в семь раз превышало содержание вольфрама, в пену не извлекаются. Полученные данные свидетельствуют о том, что для успешной флотации вольфрама из вышеприведенного сильнокислого раствора не требуется ни разбавления, ни регулирования величины рН раствора - вольфрам успешно флотируется даже из раствора, содержащєго 6,5 мол/дм ${ }^{3}$ свободной азотной кислоты.

В сухом концентрате, полученном при флотации вольфрама непосредотвенно из второго неразбавленного технологического раствора, содержится вольфрама $48 \%$, додециламина $29 \%$ и железа $0,93 \%$. Кальций в кошцентрате практически отсутствует, а остальные металлы, по данным спектрального анализа, присутствуют, как и в случае молибденового раствора, только в следовых количествах.

\section{Выводы}

1. В растворах с высокой концентрацией молибдена и вольфрама (выше. $10^{-2}$ мол/дм ${ }^{3}$ ) способность их анионных форм к флотации проявляется в значительно более кислых растворах, чем это имеет место в разбавленных растворах, вследствие чего селективность флотации этих элементов повышается. 
2. Из технологического азотнокислого раствора $\left(C_{\mathrm{HNO}_{3}}=3,05 \mathrm{moл} /\right.$ дм $^{3}$, $C_{\mathrm{Mo}}=13,27 \Gamma / \mathrm{sm}^{3}, C_{\mathrm{Fe}}=10,94 \quad \Gamma /$ дм $^{3}$ ) после 2-кратного или большего разбавления без регулирования $\mathrm{pH}$ среды при прибавлении катионного собирателя в количестве $0,6-0,8$ мол/г-атом Мо флотируется в течение нескольких минут около $90 \%$ от содержащегося в растворе молибдена.

3. Из технологического азотнокислого раствора $\left(C_{\mathrm{HNO}_{3}}=6,48 \mathrm{мол} / \mathrm{g}^{3}\right.$, $C_{\mathrm{W}}=7,9 \mathrm{\Gamma} /$ дм $^{3}, C_{\mathrm{Fe}}=0,89 \mathrm{\Gamma} /$ дм $^{3}, C_{\mathrm{Ca}}=55 \mathrm{r} /$ дм $\left.^{3}\right)$ без разбавления и регулирования величины $\mathrm{pH}$ раствора при прибавлении катионного собирателя в количестве 0,5 мол/г-атом W флотируется около $90 \%$ от содержащегося в растворе вольфрама.

4. Недостатком процесса флотации молибдена и вольфрама из неразбавленных кислых растворов является большой объемный выход пенного продукта.

\section{ЛИТЕРАТУРА}

1. Поднек А. К., Перлов М. П., Попова Ю. М. Способ извлечения вольфрама и молибдена из разбавленных растворов. - Авт. свид. СССР № 236373 . - Бюл. изобрет.. № 18 (1970).

2. Charewicz, W., Niemiec, J. Flotation of anions using cationic surfactants. Nukleonika, $1969,14, \mathrm{~N} 1,17-28$.

3. Гольман А. М., Меклер Л. Н., Николаева Т. И. и др. Разработка и внедрение технологии ионной флотации молибдена. - Изв. ВУЗбв. Цвет. металлургия, $1974,7,19-22$.

4. Lascorin, B. N., Golman, A. M., Kuznetsova, E. N. et al. Ionic flotation of molybdenum: theory and experience of commercial-scale operation. - In: Proceedings of XI International Mineral Processing Congress. Cagliari, Istituto di Arte Mineraria Universita di Cagliari, 1975, 161-183.

5. Гольман A. M. Основы ионной флотации и ее применение в гидрометаллургии. Изв, ВУЗов. Цвет. металлургия, 1981, 4, 18-28.

6. Ягодкина H. Г. Извлечение молибдена из промышленных растворов Узбекского комбината тугоплавких и жаропрочных металлов методом флотации. - В кн.: Вопросы совершенствования разработки и обөгашения полезных ископаемых . при комплексном освоении недр. М., 1979, 174-182.

$\begin{array}{cc}\text { Институт химии } & \text { Поступила в редакцию } \\ \text { Академии наук Әстонской ССР } & 16 / \mathrm{VI} 1983\end{array}$

Ille JOHANNES, R. KOCH

\section{MOLOBDEENI JA VOLFRAMI FLOTEERIMINE HAPUDEST TEHNOLOOGILISTEST LAHUSTEST}

On uuritud molübdeen(VI) ja volfram(VI) floteeritavust kahest lämmastikhappelisest tehnoloogilisest lahusest, milles nii floteeritavate elementide kui ka happe kontgentratsioon ületavad seni uuritud piirid. Katsetulemused näitavad, et molübdeeni ja volframi sisaldusel üle $10^{-2} \mathrm{~mol} / \mathrm{dm}^{3}$ laieneb tunduvalt flotoaktiivsete polüanioonide esinemispiirkond happelisemate lahuste suunas, kus floteerimise selektiivsus on suurem.

\section{Ille JOHANNES, R. KOCH}

\section{FLOTATION OF MOLYBDENUM AND TUNGSTEN FROM ACIDIC SOLUTIONS}

The flotability of $\mathrm{Mo}(\mathrm{VI})$ and $\mathrm{W}(\mathrm{VI})$ from their nitric acid technological solutions were investigated. It has been shown that at the concentrations of Mo(VI) and W(VI) above $10^{-2} \mathrm{~mole} / \mathrm{dm}^{3}$, their flotable polyanions are under a considerably higher acid concentrations than was known earlier in the case of their less concentrated solutions. 